\title{
From Drug-Induced Developmental Neuroapoptosis to Pediatric Anesthetic Neurotoxicity-Where Are We Now?
}

\author{
Catherine E. Creeley \\ Department of Psychology, State University of New York at Fredonia, Fredonia, NY 14063, USA; \\ creeley@fredonia.edu; Tel.: +1-716-673-3890 \\ Academic Editor: Balapal S. Basavarajappa \\ Received: 7 July 2016; Accepted: 12 August 2016; Published: 16 August 2016
}

\begin{abstract}
The fetal and neonatal periods are critical and sensitive periods for neurodevelopment, and involve rapid brain growth in addition to natural programmed cell death (i.e., apoptosis) and synaptic pruning. Apoptosis is an important process for neurodevelopment, preventing redundant, faulty, or unused neurons from cluttering the developing brain. However, animal studies have shown massive neuronal cell death by apoptosis can also be caused by exposure to several classes of drugs, namely gamma-aminobutyric acid (GABA) agonists and $N$-methyl-D-aspartate (NMDA) antagonists that are commonly used in pediatric anesthesia. This form of neurotoxic insult could cause a major disruption in brain development with the potential to permanently shape behavior and cognitive ability. Evidence does suggest that psychoactive drugs alter neurodevelopment and synaptic plasticity in the animal brain, which, in the human brain, may translate to permanent neurodevelopmental changes associated with long-term intellectual disability. This paper reviews the seminal animal research on drug-induced developmental apoptosis and the subsequent clinical studies that have been conducted thus far. In humans, there is growing evidence that suggests anesthetics have the potential to harm the developing brain, but the long-term outcome is not definitive and causality has not been determined. The consensus is that there is more work to be done using both animal models and human clinical studies.
\end{abstract}

Keywords: early brain development; drugs; cognitive development; neurodevelopment

\section{Introduction}

Apoptosis, known as one form of programmed cell death (PCD) or cell suicide, is a natural process by which neurons in the developing brain are selectively deleted in a process that contributes to normal neurodevelopment, before or after neuronal differentiation. PCD may delete $50 \%$ or more of all newly formed neurons, an important process critical for the formation of a highly structured and efficient fully formed human brain. In the periphery, PCD was revealed to be regulated by the competition for a limited amount of nerve growth factor (NGF), which allows for a pattern of connections to form between proliferating and target cells [1-3]. In the central nervous system (CNS), however, the process is more complex, relying on neuronal activation and neurotransmitter activity rather than the simple presence of growth factors [4-6]. Abnormal patterns of apoptosis can be triggered by altering neurotransmitter activity through exposure to psychoactive drugs. The amount of drug-induced apoptotic cell death depends on timing, dose, and duration, and can be a significant adverse event that results in a widespread neurodegeneration throughout the developing brain, which is particularly vulnerable to environmental insult during the fetal and neonatal period [7]. Of particular concern is the effect that drugs have on the developing brain, as exposure to a wide variety of drugs may significantly alter the course of neurodevelopment, which may lead to permanent changes 
and a lifetime of intellectual disability that includes both cognitive and behavioral deficits [8-12]. An underlying factor in the alteration of brain development may be drug-induced neurodevelopmental apoptosis (DIDNA). DIDNA was first identified in the neonatal rodent brain, caused by classes of drugs that have $N$-methyl-D-aspartate (NMDA) receptor antagonist or gamma-aminobutyric acid (GABA) mimetic properties, such as ethanol (which has both properties) [13-17], some drugs of abuse [18-20], anticonvulsants [21,22], sedatives, and anesthetics [23-28]. The results of early studies provided evidence that pointed to the fact that this type of neurotoxicity is a major public health concern if agents administered in obstetric and pediatric medicine could have the potential to cause brain damage. It is also not uncommon for pregnant women to abuse drugs, or to undergo therapeutic treatment that involves the use of anticonvulsants, sedatives, and anesthetics [8]. The premature infant is also routinely exposed to sedatives, analgesics, and anesthetics, sometimes for prolonged periods during a stay in the neonatal intensive care unit. Neonates and infants also may be exposed to sedatives and anesthetics for procedural sedation and surgery [29].

Results of years of research have shown that, in animals, DIDNA may cause permanent changes in brain receptor function and circuitry that results in sensorimotor, social, and cognitive deficits [30]. In humans, fetal or neonatal drug exposure has been linked to learning disabilities and behavioral/developmental deficits [8]. This converging evidence led researchers to propose the need to investigate the potential neurotoxicity of pediatric sedatives and anesthetics [31]. The objective of this paper is to review the seminal animal experiments on DIDNA and examine the current status of the evidence regarding pediatric anesthetic neurotoxicity in humans.

\section{Methods}

This is a review of the research that has been a part of a major scientific movement in the field to design and conduct animal and human studies that set out to answer the research question as to whether or not pediatric sedatives and anesthetics are neurotoxic to the developing brain. This review begins with the seminal research from the laboratory of John W. Olney beginning in 1999 [25], and follows the progress from there, ending with the most recent clinical studies that have been completed as of June 2016. The PubMed database was used to search for relevant literature using keyword searches for original research and review articles that included the following terms: anesthesia/anesthetics, pediatric anesthesia/sedation, neurodevelopment, apoptosis, and neurodegeneration.

\section{DIDNA}

The finding that drug exposure can cause changes in the neurodevelopment is decades old, with an early focus mostly on drugs of abuse such as alcohol [32] and morphine [33]. There were few studies on therapeutic exposure to sedatives and anesthetics [23,24]. The discovery of DIDNA was first identified by the Olney lab at Washington University School of Medicine in St. Louis when Ikonomidou et al. [25] found that NMDA antagonist drugs caused widespread apoptotic cell death in the neonatal rat brain. In a series of subsequent reports from the Olney lab they showed that a similar effect could be observed in the rat or mouse brain by several other types of drugs, including $\gamma$-aminobutyric acid type A $\left(\mathrm{GABA}_{\mathrm{A}}\right)$ mimetics, and drugs with combined GABA mimetic and NMDA antagonist properties, such as ethanol, anticonvulsants, drug combinations, and anesthetic agents such as ketamine, midazolam, propofol, and isoflurane [13-15,20,25-28]. It was determined, and is now widely accepted, that the brain growth spurt period is when the fetal or infant brain is most vulnerable to DIDNA. In rodents this period is postnatal, during the first week of life. In the human brain, this period begins during fetal development and extends throughout early childhood [34]. Vulnerability to DIDNA is not limited to just one brain region, and has been found to occur through the entire brain including the forebrain, midbrain, cerebellum, and visual system $[13-15,35,36]$. The pattern of cell death is dependent on the timing of exposure during synaptogenesis. The underlying mechanism was shown to be Bax-dependent and to involve mitochondrial injury, extramitochondrial leakage 
of cytochrome c, and activation of caspase-3 [37-39]. Subsequent studies provided evidence that brain-derived neurotrophic factor-dependent and death receptor-dependent pathways were also involved [39-41].

This early evidence was not immediately accepted - the translational relevance to the human clinical experience was questioned, based on observations that the doses and durations used in the animal models were too high and for too long, respectively [42-44]. It was subsequently argued that a clinically relevant dose is dependent upon effect for the given species. For example, the doses of anesthetics that should be tested are those that produce a specified anesthetic effect in animals or humans, and these doses may not be the same on a strictly $\mathrm{mg} / \mathrm{kg}$ basis. When this metric based on a clinically effective dose is applied, the cross-species comparison can be made [45]. In the next 10 years, DIDNA was confirmed by multiple labs using in vitro and in vivo animal models, including the non-human primate [46-50]. As the debate among researchers and clinicians began about whether these results should influence clinical practice [51-53], multiple reviews of the animal research all came to the same conclusion-results animal studies on drug-induced neurotoxicity were robust enough to suggest that anesthetics and sedatives used in pediatric and obstetric medicine may have the ability to damage the developing brain, and clinical research was needed [54-58]. The research focus moved from the preclinical to the clinical realm, leading to the establishment of national and international research consortiums, groups, and organizations devoted to determining if anesthetics pose a significant risk to the developing human brain [59-62].

\section{Clinical Investigations}

Certainly the discovery and documentation of fetal alcohol syndrome as early as the 1970s was an early indicator that there could be serious consequences to exposing the developing brain to other psychoactive drugs [32], especially those that, either alone or in combination, influence GABA agonist and NMDA antagonist activity in the brain. Based on the initial results published by Olney and colleagues [13-15,25-28], pediatric anesthetic regimens were identified as suspect because they use drugs that have GABA mimetic or NMDA antagonist properties. Researchers began clinical retrospective research using archived data sets from a population of children, already exposed to anesthesia, available for analysis. Respectably, an international clinical research community set to work. In 2009, published results of retrospective studies of children exposed to anesthesia before age 3 suggested that there may be an association between early exposure to anesthesia and an increased risk of behavioral/developmental disorders [63-65]. The results of these studies were consistent with earlier studies that, until this point, had not received much attention from clinicians and researchers in the field $[66,67]$. Taken together, this evidence suggested that early anesthesia exposure could result in poor neurodevelopmental outcomes that persist into childhood.

Not all studies found an association, however [68], and this early research did not immediately sway clinical opinion, as prospective studies had not been conducted and causality could absolutely not be determined [69-72]. Subsequent research added to the evidence that neonatal exposure to anesthesia may, or may not, have long-term adverse effects on behavioral and cognitive development (see Table 1). Overall, the findings suggest that early multiple exposures to surgery/anesthetics may increase the risk for a behavioral developmental disorder, but a single exposure likely does not [73-76]. 
Table 1. Clinical research conducted to investigate the effects of early exposure to anesthesia, in order by publication date.

\begin{tabular}{|c|c|c|c|c|c|c|c|}
\hline First Author & Date & $\begin{array}{c}\text { Age at } \\
\text { Exposure }\end{array}$ & Study Groups & Drugs & Study Design and Population & $\begin{array}{l}\text { Outcome Measure } \\
\text { and Endpoint }\end{array}$ & Conclusions \\
\hline Roze [77] & 2008 & $<33$ weeks & $\begin{array}{l}\text { Exposed }(n=115) ; \text { non-exposed } \\
\qquad(n=1457)\end{array}$ & $\begin{array}{l}\text { Daily exposure to sedatives } \\
\text { and/or opioids }\end{array}$ & $\begin{array}{l}\text { Prospective, population-based } \\
\text { study, France }\end{array}$ & Presence of disability at age 5 & $\begin{array}{l}\text { Prolonged sedation/analgesia } \\
\text { ( }>7 \text { days) not associated with } \\
\text { poor outcome }\end{array}$ \\
\hline Kalkman [78] & 2009 & $<2$ years & $\begin{array}{l}<24 \text { months }(n=178) ; \\
>24 \text { months }(n=65)\end{array}$ & $\begin{array}{l}\text { Isoflurane, halothane, } \\
\text { enflurane, fentanyl, sufentanil }\end{array}$ & $\begin{array}{l}\text { Retrospective cohort } \\
\text { study, Netherlands }\end{array}$ & Child Behavior Checklist & $\begin{array}{l}\text { No ability to confirm an effect, } \\
\text { study underpowered }\end{array}$ \\
\hline Wilder [65] & 2009 & $<4$ years & $\begin{array}{l}\text { No exposure }(n=4,764) \\
\text { Single }(n=449) \\
\text { Multiple }(n=144)\end{array}$ & $\begin{array}{l}\text { Isoflurane, halothane, } \\
\text { enflurane, sodium thiopental, } \\
\text { etomidate, ketamine, nitrous } \\
\text { oxide, diazepam }\end{array}$ & $\begin{array}{l}\text { Population-based, retrospective } \\
\text { birth cohort study; USA }\end{array}$ & $\begin{array}{l}\text { Reading, language, and math } \\
\text { LDs before age } 19\end{array}$ & $\begin{array}{l}\text { Significant increased risk of } \\
\text { LD with multiple, but not } \\
\text { single exposure }\end{array}$ \\
\hline Bartels [68] & 2009 & $<3$ years & $\begin{array}{l}\text { Exposure before age } 3 \text { vs. } \\
\text { exposure age } 3-12 ; \\
n=1143 \text { twin pairs }\end{array}$ & $\begin{array}{l}\text { Information not available } \\
\text { to researchers }\end{array}$ & $\begin{array}{c}\text { Monozygotic } \\
\text { concordant-discordant twin study, } \\
\text { Netherlands Twin Registry }\end{array}$ & $\begin{array}{l}\text { Educational achievement and } \\
\text { cognitive problems at age } 12\end{array}$ & $\begin{array}{l}\text { No difference between } \\
\text { exposed and unexposed twin }\end{array}$ \\
\hline Sprung [64] & 2009 & Perinatal & $\begin{array}{c}\text { Cesarian }(n=497) \text { vs. } \\
\text { vaginal delivery }(n=4823)\end{array}$ & $\begin{array}{l}\text { Isoflurane, halothane, } \\
\text { enflurane, sodium thiopental, } \\
\text { etomidate, ketamine, nitrous } \\
\text { oxide, methoxyflurane }\end{array}$ & Population-based birth cohort: USA & $\begin{array}{l}\text { Incidence of learning } \\
\text { disability (LD) before age } 19\end{array}$ & $\begin{array}{l}\text { No association between } \\
\text { anesthetic exposure during } \\
\text { birth and risk of LD }\end{array}$ \\
\hline DiMaggio [63] & 2009 & $\leq 3$ years & $\begin{array}{l}\text { Hernia repair }(n=383) \text { vs. } \\
\text { Age-matched controls } \\
\qquad(n=5050)\end{array}$ & Not provided & $\begin{array}{l}\text { Retrospective cohort study of } \\
\text { hernia patients; NY State Medicaid } \\
\text { Program enrollees, USA }\end{array}$ & $\begin{array}{l}\text { Risk of } \\
\text { behavioral/develop-mental } \\
\text { disorder diagnosis at or } \\
\text { before age } 4\end{array}$ & $\begin{array}{l}\text { Children who had hernia } \\
\text { repair }>2 x \text { as likely to be } \\
\text { diagnosed }\end{array}$ \\
\hline Hansen [79] & 2011 & $<1$ year & $\begin{array}{l}\text { Hernia repair }(n=2689) \text { vs. } \\
\text { Age-matched controls }(14,575)\end{array}$ & Not provided & $\begin{array}{l}\text { Retrospective birth cohort } \\
\text { study, Denmark }\end{array}$ & $\begin{array}{l}\text { Academic achievement test at } \\
15 \text { or } 16 \text { years }\end{array}$ & $\begin{array}{l}\text { No evidence of any effects of } \\
\text { a single exposure }\end{array}$ \\
\hline Guerra [80] & 2011 & $\leq 6$ weeks & $\begin{array}{l}\text { Cardiac surgery }(n=95) \\
\text { dose-response }\end{array}$ & $\begin{array}{l}\text { Inhalationals, opioids, } \\
\text { benzodiazepines, ketamine, } \\
\text { chloral hydrate }\end{array}$ & $\begin{array}{l}\text { Prospective post-operative } \\
\text { follow-up }\end{array}$ & $\begin{array}{l}\text { Mental, motor, and } \\
\text { vocabulary assessment at } \\
18-24 \text { months }\end{array}$ & $\begin{array}{l}\text { No association between } \\
\text { dose/durationof } \\
\text { sedation/analgesia and } \\
\text { neurodevelopmental outcome }\end{array}$ \\
\hline DiMaggio [73] & 2011 & $<3$ years & $\begin{array}{c}\text { Surgery before age } 3 \\
\text { (1-3 exposures) }(n=304) \text { vs. } \\
\text { unexposed controls }(n=10,146)\end{array}$ & $\begin{array}{l}\text { Information not available } \\
\text { to researchers }\end{array}$ & $\begin{array}{l}\text { Retrospective sibling birth cohort } \\
\text { design; NY State Medicaid } \\
\text { Program enrollees, USA }\end{array}$ & $\begin{array}{l}\text { Incidence of developmental } \\
\text { and behavioral disorder at or } \\
\text { before age } 6\end{array}$ & $\begin{array}{l}\text { Anesthesia-exposed group } \\
\text { risk of diagnosis } 60 \% \text { higher; } \\
\text { no causal connection can } \\
\text { be made }\end{array}$ \\
\hline
\end{tabular}


Table 1. Cont.

\begin{tabular}{|c|c|c|c|c|c|c|c|}
\hline First Author & Date & $\begin{array}{c}\text { Age at } \\
\text { Exposure }\end{array}$ & Study Groups & Drugs & Study Design and Population & $\begin{array}{l}\text { Outcome Measure } \\
\text { and Endpoint }\end{array}$ & Conclusions \\
\hline Flick [74] & 2011 & $<2$ years & $\begin{array}{c}\text { General anesthesia exposure } \\
\text { once }(n=286) \text {, more than once } \\
(n=64) \text { vs. unexposed controls } \\
(n=700)\end{array}$ & $\begin{array}{l}\text { Combination of halothane } \\
\text { and nitrous oxide } \\
\text { (most common) }\end{array}$ & $\begin{array}{l}\text { Retrospective matched } \\
\text { cohort study, USA }\end{array}$ & $\begin{array}{l}\text { LD diagnosis, achievement, } \\
\text { cognitive tests before age } 19\end{array}$ & $\begin{array}{l}\text { Multiple exposures to } \\
\text { anesthesia increases risk } \\
\text { for a } L D \text {, but no } \\
\text { intervention required }\end{array}$ \\
\hline Sprung [75] & 2012 & $<2$ years & $\begin{array}{l}\text { No exposure }(n=10,146) ; \\
\text { single exposure }(n=210) ; \\
\text { two exposures }(n=71) ; \\
\text { three or more }(n=23)\end{array}$ & $\begin{array}{l}\text { Combination of halothane } \\
\text { and nitrous oxide } \\
\text { (most common) }\end{array}$ & $\begin{array}{l}\text { Retrospective birth cohort } \\
\text { design, USA }\end{array}$ & $\begin{array}{l}\text { Attention-deficit/hyperactivty } \\
\text { (ADHD) diagnosis before } \\
\text { age } 19\end{array}$ & $\begin{array}{l}\text { No increased risk with single } \\
\text { exposure, but increased risk } \\
\text { for ADHD diagnosis with } \\
\text { repeated exposure }\end{array}$ \\
\hline Ing [81] & 2014 & $<3$ years & $\begin{array}{l}\text { Disability class: none }(n=1135) ; \\
\text { language and cognitive }(n=96) ; \\
\text { behavioral deficits }(n=151) ; \\
\text { severe deficits }(n=62)\end{array}$ & Information not available & $\begin{array}{l}\text { Retrospective birth cohort study, } \\
\text { Western Australian Pregnancy } \\
\text { Cohort (Raine) Study }\end{array}$ & $\begin{array}{l}\text { Language, cognition, motor } \\
\text { skills and behavior at age } 10\end{array}$ & $\begin{array}{l}\text { Deficits in language and } \\
\text { abstract reasoning associated } \\
\text { with anesthesia exposure. } \\
\text { Phenotype of interest } \\
\text { may be specific } \\
\text { language/cognitive delays }\end{array}$ \\
\hline Кo [82] & 2014 & $<3$ years & $\begin{array}{l}\text { Exposed }(n=3293) \text { vs. } \\
\text { unexposed }(n=16,465)\end{array}$ & Sevoflurane & $\begin{array}{l}\text { Population-based retrospective } \\
\text { matched birth cohort design, } \\
\text { National Health Insurance } \\
\text { Database of Taiwan }\end{array}$ & Risk of ADHD before age 10 & $\begin{array}{l}\text { No increased risk of ADHD } \\
\text { diagnosis for single or } \\
\text { multiple exposure }\end{array}$ \\
\hline Ko [83] & 2015 & $<2$ years & $\begin{array}{l}\text { Exposed }(n=5197) \text { vs. } \\
\text { unexposed }(n=20,788)\end{array}$ & Sevoflurane & $\begin{array}{l}\text { Population-based, retrospective } \\
\text { matched birth cohort design, } \\
\text { National Health Insurance } \\
\text { Database of Taiwan }\end{array}$ & $\begin{array}{l}\text { Risk of autism disorder } \\
\text { diagnosis before age } 10\end{array}$ & $\begin{array}{l}\text { No increased risk of AD; no } \\
\text { relationship between total } \\
\text { number of exposures and } \\
\text { AD risk }\end{array}$ \\
\hline Creagh [84] & 2015 & $<3$ years & $\begin{array}{l}\text { ASD diagnosed }(n=262) \text { vs. } \\
\text { non-ASD }(n=253)\end{array}$ & $\begin{array}{l}\text { In utero exposure-specific } \\
\text { agents not known }\end{array}$ & $\begin{array}{l}\text { Population-based sibling cohort } \\
\text { study, Puerto Rico }\end{array}$ & $\begin{array}{l}\text { Risk of autism spectrum } \\
\text { disorder (ASD) diagnosis }\end{array}$ & $\begin{array}{l}\text { Early exposure to } \\
\text { anesthesia not linked to } \\
\text { an ASD diagnosis }\end{array}$ \\
\hline Gleich [85] & 2015 & $<3$ years & $\begin{array}{c}\text { No exposure }(n=250) ; \\
\text { single }(n=150) ; \\
\text { multiple }(n=100) ; \\
\text { Hypothetical sample sizes }\end{array}$ & Data to be collected & $\begin{array}{l}\text { Population-based, retrospective } \\
\text { propensity-matched study, USA }\end{array}$ & $\begin{array}{l}\text { Neuropsychological test } \\
\text { battery (also used in } \\
\text { primates), ages } 8-12 \text { or } 15-19\end{array}$ & $\begin{array}{l}\text { Analyses not completed; } \\
\text { goal is to determine whether } \\
\text { a neurobehavioral } \\
\text { phenotype exists }\end{array}$ \\
\hline $\mathrm{Hu}[86]$ & 2016 & $<3$ years & $\begin{array}{c}\text { No exposure }(n=465) \\
\text { single exposure }(n=466) ; \\
\text { multiple exposure }(n=126)\end{array}$ & Data to be collected & $\begin{array}{l}\text { Population-based, } \\
\text { retrospective birth cohort }\end{array}$ & $\begin{array}{l}\text { LD or ADHD diagnosis, } \\
\text { group achievement test at } \\
\text { age } 5 \text { or } 6\end{array}$ & $\begin{array}{l}\text { Only slight differences } \\
\text { between study groups, not } \\
\text { expected to affect future data } \\
\text { analysis comparing risk }\end{array}$ \\
\hline Sun [76] & 2016 & $<3$ years & $\begin{array}{c}\text { Sibling pairs }(n=105) ; \\
\text { single exposure vs. unexposed }\end{array}$ & Inhaled anesthetic agents & $\begin{array}{l}\text { Sibling matched cohort study, } \\
\text { at } 4 \text { U.S. University-based hospitals }\end{array}$ & $\begin{array}{l}\text { Global cognitive function } \\
\text { (IQ) at age } 10\end{array}$ & $\begin{array}{l}\text { No risk for healthy children } \\
\text { with single exposure }\end{array}$ \\
\hline
\end{tabular}


In an attempt to synthesize the clinical data from retrospective studies, DiMaggio et al. [87] conducted a search of studies published from 2002 to $2012[63-65,68,73-75,77-80,88]$ and conducted a Bayesian analysis of selected studies $[63,65,68,77,78,80,88]$. The authors concluded that the results indicated a modest, but elevated risk of adverse behavioral/developmental outcomes, but that the uncertainty of the available epidemiological evidence might preclude further research using existing data sources. The focus then shifted to studies designed to investigate associations between anesthetic exposure and a diagnosis for specific disorders such as learning disorder (LD), attention-deficit/hyperactivity disorder (ADHD), and autism spectrum disorders (ASD), but no associations were found $[66,67,82-84]$. It has since been suggested that studies should be designed that focus on more specific outcome measures, because the variability in the results of clinical data may be due to lack of consistent and well-defined dependent measures, such as tests designed to assess specific cognitive and behavioral deficits, rather than more global measures using an intelligence quotient (IQ) or performance on academic achievement tests. For example, Ing et al. [81] did show that results were dependent on clinical outcome measures used-there was evidence for an increased risk for specific cognitive deficits, but no increased risk was observed when academic achievement results were analyzed. This new focus on outcomes could lead to future studies that reveal deficits to be domain-specific and may be unable to be discovered using global measures such as IQ, LD diagnoses, or group academic achievement tests. Future research is dedicated to minimizing confounds, maximizing control, and using specific test batteries to characterize a neurobehavioral phenotype that is specifically associated with anesthetic neurotoxicity [81,84-86,89-92]. New patient populations are also being considered [93,94], but are complicated and have raised important new questions about potential perioperative risks that are also potential sources of brain injury (i.e., hypotension, hypoxia/ischemia, hypocapnia) [95]. The debate among researchers and clinicians has been vigorous and productive-several review articles have been written in the past few years that simultaneously acknowledge a potential risk and conclude that we simply cannot know if anesthesia causes neurotoxic effects in the human brain that would require a change in clinical practice or if this risk should be included as part of informed consent. Most agree, however, that important questions remain that cannot be answered without continued preclinical and clinical research [95-103].

\section{Conclusions}

\section{Summary of Findings}

- There is abundant evidence from animal research that suggests that pediatric sedation and anesthesia has the potential to be neurotoxic in the developing brain.

- Studies in humans are mostly retrospective, and have found that a single exposure to anesthesia is likely not a concern, but it cannot be ruled out that multiple exposures could increase the risk for poor neurodevelopmental outcome.

- Prospective human clinical research is needed; retrospective studies should focus on neurobehavioral and domain-specific outcome measures rather than diagnoses or global outcomes such as standardized test and academic achievement scores.

- New research in animals should focus on finding the safest protocols, drugs, and drug combinations.

- There is not enough evidence to prompt significant changes in clinical practice, but elective or non-urgent surgeries should be avoided.

- More research is needed - preclinical and clinical.

There is no question that this issue has become a global health concern, and a network of research labs and groups has been actively pursuing answers that will lead to best practice. It is also the case that the issue of anesthetic neurotoxicity is debatable-not everyone is convinced that it is anesthesia that presents the greatest risk. Inherent limitations to research with human participants that start with the intrinsic differences within the patient population, and are often underpowered 
and heavily confounded by differences among and between groups place major limitations on our ability to accurately link anesthesia to long-term developmental outcomes. It should also be noted that other drugs that do not cause apoptotic neurodegeneration in the brain are also linked to poor neurodevelopmental outcomes. The simple fact of the matter is that exposure to anesthesia is unavoidable and necessary to mitigate pain and distress, which itself has been shown to have adverse effects on development. Future directions are to conduct more prospective studies and to design more controlled retrospective studies that include the use of domain-specific outcome measures. The overall goal is to prevent or limit any potential brain injury using evidence-based clinical strategies. The evidence thus far is not strong enough to change clinical practice, but has asked and answered important questions that have rightly advanced our knowledge in significant ways.

Conflicts of Interest: The author declares no conflict of interest.

\section{References}

1. Barde, Y.A. Trophic factors and neuronal survival. Neuron 1989, 2, 1525-1534. [CrossRef]

2. Hamburger, V. Trophic interactions in neurogenesis: A personal historical account. Ann. Rev. Neurosci. 1980, 3, 269-278. [CrossRef] [PubMed]

3. Levi-Montalcini, R. The nerve growth factor 35 years later. Science 1987, 237, 1154-1162. [CrossRef] [PubMed]

4. Heck, N.; Golbs, A.; Riedemann, T.; Sun, J.J.; Lessmann, V.; Luhmann, H.J. Activity-dependent regulation of neuronal apoptosis in neonatal mouse cerebral cortex. Cerebr. Cortex 2008, 18, 1335-1349. [CrossRef] [PubMed]

5. Dekkers, M.P.J.; Nikoletopoulou, V.; Barde, Y.-A. Death of developing neurons: New insights and implications for connectivity. J. Cell Biol. 2013, 203, 385-393. [CrossRef] [PubMed]

6. Tremblay, R.; Hewitt, K.; Lesiuk, H.; Mealing, G.; Morley, P.; Durkin, J.P. Evidence that brain-derived neurotrophic factor neuroprotection is linked to its ability to reverse the NMDA-induced inactivation of protein kinase C in cortical neurons. J. Neurochem. 1999, 72, 102-111. [CrossRef] [PubMed]

7. Meredith, R.M. Sensitive and critical periods during neurotypical and aberrant neurodevelopment: A framework for neurodevelopmental disorders. Neurosci. Biobehav. Rev. 2015, 50, 180-188. [CrossRef] [PubMed]

8. Ross, E.J.; Graham, D.L.; Money, K.M.; Stanwood, G.D. Developmental consequences of fetal exposure to drugs: What we know and what we still must learn. Neuropsychopharmacology 2015, 40, 61-87. [CrossRef] [PubMed]

9. Stanwood, G.D.; Levitt, P. Drug exposure early in life: Functional repercussions of changing neuropharmacology during sensitive periods of brain development. Curr. Opin. Pharmacol. 2004, 4, 65-71. [CrossRef] [PubMed]

10. Chiriboga, C.A. Fetal alcohol and drug effects. Neurologist 2003, 9, 267-279. [CrossRef] [PubMed]

11. Sood, B.; Delaney-Black, V.; Covington, C.; Nordstrom-Klee, B.; Ager, J.; Templin, T.; Janisse, J.; Martier, S.; Sokol, R.J. Prenatal alcohol exposure and childhood behavior at age 6 to 7 years: I. dose-response effect. Pediatrics 2001, 108, E34. [CrossRef] [PubMed]

12. Verrotti, A.; Scaparrotta, A.; Cofini, M.; Chiarelli, F.; Tiboni, G.M. Developmental neurotoxicity and anticonvulsant drugs: A possible link. Reprod. Toxicol. 2014, 48, 72-80. [CrossRef] [PubMed]

13. Olney, J.W.; Tenkova, T.; Dikranian, K.; Qin, Y.Q.; Labruyere, J.; Ikonomidou, C. Ethanol-induced apoptotic neurodegeneration in the developing C57BL/6 mouse brain. Dev. Brain Res. 2002, 133, 115-126. [CrossRef]

14. Ikonomidou, C.; Bittigau, P.; Ishimaru, M.J.; Wozniak, D.F.; Koch, C.; Genz, K.; Price, M.T.; Stefovska, V.; Horster, F.; Tenkova, T.; et al. Ethanol-induced apoptotic neurodegeneration and fetal alcohol syndrome. Science 2000, 287, 1056-1060. [CrossRef] [PubMed]

15. Dikranian, K.; Ishimaru, M.J.; Tenkova, T.; Labruyere, J.; Qin, Y.Q.; Ikonomidou, C.; Olney, J.W. Apoptosis in the in vivo mammalian forebrain. Neurobiol. Dis. 2001, 8, 359-379. [CrossRef] [PubMed]

16. Lebedeva, J.; Zakharov, A.; Ogievetsky, E.; Minlebaeva, A.; Kurbanov, R.; Gerasimova, E.; Sitdikova, G.; Khazipov, R. Inhibition of cortical activity and apoptosis caused by ethanol in neonatal rats in vivo. Cerebr. Cortex 2015. [CrossRef] [PubMed] 
17. Smith, C.C.; Guévremont, D.; Williams, J.M.; Napper, R.M. Apoptotic cell death and temporal expression of apoptotic proteins $\mathrm{Bcl}-2$ and Bax in the hippocampus following binge ethanol in the neonatal rat model. Alcohol. Clin. Exp. Res. 2015, 39, 36-44. [CrossRef] [PubMed]

18. Mao, J.; Sung, B.; Ji, R.R.; Lim, G. Neuronal apoptosis associated with morphine tolerance: Evidence for an opioid-induced neurotoxic mechanism. J. Neurosci. 2002, 22, 7650-7661. [PubMed]

19. Hu, S.; Sheng, W.S.; Lokensgard, J.R.; Peterson, P.K. Morphine induces apoptosis of human microglia and neurons. Neuropharmacology 2002, 42, 829-836. [CrossRef]

20. Yuede, C.M.; Wozniak, D.F.; Creeley, C.E.; Taylor, G.T.; Olney, J.W.; Farber, N.B. Behavioral consequences of NMDA antagonist-induced neuroapoptosis in the infant mouse brain. PLoS ONE 2010, 5, e11374. [CrossRef] [PubMed]

21. Bittigau, P.; Sifringer, M.; Genz, K.; Reith, E.; Pospischil, D.; Govindarajalu, S.; Dzietko, M.; Pesditschek, S.; Mai, I.; Dikranian, K.; et al. Antiepileptic drugs and apoptotic neurodegeneration in the developing brain. Proc. Natl. Acad. Sci. USA 2002, 99, 15089-15094. [CrossRef] [PubMed]

22. Kaushal, S.; Tamer, Z.; Opoku, F.; Forcelli, P.A. Anticonvulsant drug-induced cell death in the developing white matter of the rodent brain. Epilepsia 2016, 57, 727-734. [CrossRef] [PubMed]

23. Levin, E.D.; Uemura, E.; DeLuna, R.; Franks, P.; Bowman, R.E. Neurobehavioral effects of chronic halothane exposure during developmental and juvenile periods in the rat. Exp. Neurol. 1987, 98, 584-593. [CrossRef]

24. Uemura, E.; Ireland, W.P.; Levin, E.D.; Bowman, R.E. Effects of halothane on the development of rat brain: A golgi study of dendritic growth. Exp. Neurol. 1985, 89, 503-519. [CrossRef]

25. Ikonomidou, C.; Bosch, F.; Miksa, M.; Bittigau, P.; Vöckler, J.; Dikranian, K.; Tenkova, T.I.; Stefovska, V.; Turski, L.; Olney, J.W. Blockade of NMDA receptors and apoptotic neurodegeneration in the developing brain. Science 1999, 283, 70-74. [CrossRef] [PubMed]

26. Young, C.; Jevtovic-Todorovic, V.; Qin, Y.Q.; Tenkova, T.; Wang, H.; Labruyere, J.; Olney, J.W. Potential of ketamine and midazolam, individually or in combination, to induce apoptotic neurodegeneration in the infant mouse brain. Br. J. Pharmacol. 2005, 146, 189-197. [CrossRef] [PubMed]

27. Johnson, S.A.; Young, C.; Olney, J.W. Isoflurane-induced neuroapoptosis in the developing brain of non-hypoglycemic mice. J. Neurosurg. Anesth. 2008, 20, 21-28. [CrossRef] [PubMed]

28. Jevtovic-Todorovic, V.; Hartman, R.E.; Izumi, Y.; Benshoff, N.D.; Dikranian, K.; Zorumski, C.F.; Olney, J.W.; Wozniak, D.F. Early exposure to common anesthetic agents causes widespread neurodegeneration in the developing rat brain and persistent learning deficits. J. Neurosci. 2003, 23, 876-882. [CrossRef] [PubMed]

29. Gozal, D.; Mason, K.P. Pediatric Sedation: A Global Challenge. Int. J. Pediatr. 2010. [CrossRef] [PubMed]

30. Olney, J.W. Focus on apoptosis to decipher how alcohol and many other drugs disrupt brain development. Front. Pediatr. 2014, 2, 81. [CrossRef] [PubMed]

31. Creeley, C.E.; Olney, J.W. The young: Neuroapoptosis induced by anesthetics and what to do about it. Anesth. Analg. 2010, 110, 442-448. [CrossRef] [PubMed]

32. Jones, K.L.; Smith, D.W. The fetal alcohol syndrome. Teratology 1975, 12, 1-10. [CrossRef] [PubMed]

33. Tsang, D.; $\mathrm{Ng}$, S.C. Effect of antenatal exposure to opiates on the development of opiate receptors in rat brain. Brain Res. 1980, 188, 199-206. [CrossRef]

34. Dobbing, J.; Sands, J. The brain growth spurt in various mammalian species. Early Hum. Dev. 1979, 3, 79-84. [CrossRef]

35. Dikranian, K.; Qin, Y.Q.; Labruyere, J.; Nemmers, B.; Olney, J.W. Ethanol-induced neuroapoptosis in the developing rodent cerebellum and related brain stem structures. Dev. Brain Res. 2005, 155, 1-13. [CrossRef] [PubMed]

36. Tenkova, T.; Young, C.; Dikranian, K.; Olney, J.W. Ethanol-induced apoptosis in the visual system during synaptogenesis. Investig. Ophthalmol. Vis. Sci. 2003, 44, 2809-2817. [CrossRef]

37. Young, C.; Klocke, B.J.; Tenkova, T.; Choi, J.; Labruyere, J.; Qin, Y.Q.; Holtzman, D.M.; Roth, K.A.; Olney, J.W. Ethanol-induced neuronal apoptosis in the in vivo developing mouse brain is BAX dependent. Cell Death Differ. 2003, 10, 1148-1155. [CrossRef] [PubMed]

38. Young, C.; Roth, K.A.; Klocke, B.J.; West, T.; Holtzman, D.M.; Labruyere, J.; Qin, Y.Q.; Dikranian, K.; Olney, J.W. Role of caspase-3 in ethanol-induced developmental neurodegeneration. Neurobiol. Dis. 2005, 20, 608-614. [CrossRef] [PubMed] 
39. Yon, J.H.; Daniel-Johnson, J.; Carter, L.B.; Jevtovic-Todorovic, V. Anesthesia induces suicide in the developing rat brain via the intrinsic and extrinsic apoptotic pathways. Neuroscience 2005, 135, 815-827. [CrossRef] [PubMed]

40. Yon, J.H.; Carter, L.B.; Reiter, R.J.; Jevtovic-Todorovic, V. Melatonin reduces the severity of anesthesia-induced apoptotic neurodegeneration in the developing rat brain. Neurobiol. Dis. 2006, 21, 522-530. [CrossRef] [PubMed]

41. Lu, L.X.; Yon, J.H.; Carter, L.B.; Jevtovic-Todorovic, V. General anesthesia activates BDNF-dependent neuroapoptosis in the developing rat brain. Apoptosis 2006, 11, 1603-1615. [CrossRef] [PubMed]

42. Anand, K.J.S.; Soriano, S.G. Anesthetic agents and the immature brain: Are these toxic or therapeutic? Anesthesiology 2004, 101, 527-530. [CrossRef] [PubMed]

43. Soriano, S.G.; Loepke, A.W. Let's not throw the baby out with the bath water: Potential neurotoxicity of anesthetic drugs in infants and children. J. Neurosurg. Anesthesiol. 2005, 17, 207-209. [CrossRef] [PubMed]

44. Soriano, S.G.; Anand, K.J. Anesthetics and brain toxicity. Curr. Opin. Anaesthesiol. 2005, 18, $293-297$. [CrossRef] [PubMed]

45. Jevtovic-Todorovic, V.; Olney, J.W. PRO: Anesthesia-induced developmental neuroapoptosis: Status of the evidence. Anesth. Analg. 2008, 106, 1659-1663. [CrossRef] [PubMed]

46. Wang, C.; Kaufmann, J.A.; Sanchez-Ross, M.G.; Johnson, K.M. Mechanisms of N-methyl-D-aspartate-induced apoptosis in phencyclidine-treated cultured forebrain neurons. J. Pharmacol. Exp. Ther. 2000, 294, 287-295. [PubMed]

47. Wang, C.; Fridley, J.; Johnson, K.M. The role of NMDA receptor upregulation in phencyclidine-induced cortical apoptosis in organotypic culture. Biochem. Pharmacol. 2005, 69, 1373-1383. [CrossRef] [PubMed]

48. Wang, C.; Sadovova, N.; Fu, X.; Schmued, L.; Scallet, A.; Hanig, J.; Slikker, W. The role of the $\mathrm{N}$-methyl-D-aspartate receptor in ketamine-induced apoptosis in rat forebrain culture. Neuroscience 2005, 132, 967-977. [CrossRef] [PubMed]

49. Slikker, W., Jr.; Zou, X.; Hotchkiss, C.E.; Divine, R.L.; Sadovova, N.; Twaddle, N.C.; Doerge, D.R.; Scallet, A.C.; Patterson, T.A.; Hanig, J.P.; et al. Ketamine-induced neuronal cell death in the perinatal rhesus monkey. Toxicol. Sci. 2007, 98, 145-158. [CrossRef] [PubMed]

50. Zou, X.; Patterson, T.A.; Divine, R.L.; Sadovova, N.; Zhang, X.; Hanig, J.P.; Paule, M.G.; Slikker, W., Jr.; Wang, C. Prolonged exposure to ketamine increases neurodegeneration in the developing monkey brain. Int. J. Dev. Neurosci. 2009, 27, 727-731. [CrossRef] [PubMed]

51. Anand, K.J.S. Anesthetic neurotoxicity in newborns. Should we change clinical practice? Anesthesiology 2007, 107, 2-4. [CrossRef] [PubMed]

52. Istaphanous, G.K.; Loepke, A.W. General Anesthetics and the developing brain. Curr. Opin. Anaesthesiol. 2009, 22, 368. [CrossRef] [PubMed]

53. Vutskits, L. Anesthetic-related neurotoxicity and the developing brain: Shall we change practice? Paediatr. Drugs 2012, 14, 13-21. [CrossRef] [PubMed]

54. Mellon, R.D.; Simone, A.F.; Rappaport, B.A. Use of anesthetic agents in neonates and young children. Anesth. Analg. 2007, 104, 509-520. [CrossRef] [PubMed]

55. Loepke, A.W.; Soriano, S.G. An assessment of the effects of general anesthetics on developing brain structure and neurocognitive function. Anesth. Analg. 2008, 106, 1681-1707. [CrossRef] [PubMed]

56. Wang, C.; Slikker, W., Jr. Strategies and experimental models for evaluating anesthetics: Effects on the developing nervous system. Anesth. Analg. 2008, 106, 1643-1658. [CrossRef] [PubMed]

57. McCann, M.E.; Soriano, S.G. General Anesthetics in pediatric anesthesia: Influences on the developing brain. Curr. Drug Targets 2012, 13, 944-951. [CrossRef] [PubMed]

58. Sun, L.S.; Li, G.; Dimaggio, C.; Byrne, M.; Rauh, V.; Brooks-Gunn, J.; Kakavouli, A.; Wood, A.; Coinvestigators of the Pediatric Anesthesia Neurodevelopment Assessment (PANDA) Research Network. Anesthesia and neurodevelopment in children: Time for an answer? Anesthesiology 2008, 109, 757-761. [CrossRef] [PubMed]

59. Sun, L.S.; Li, G.; DiMaggio, C.J.; Byrne, M.W.; Ing, C.; Miller, T.L.; Bellinger, D.C.; Han, S.; McGowan, F.X. Feasibility and pilot study of the Pediatric Anesthesia NeuroDevelopment Assessment (PANDA) project. J. Neurosurg. Anesthesiol. 2012, 24, 382-388. [CrossRef] [PubMed]

60. SmartTots. Available online: http:/ / smarttots.org/ (accessed on 27 June 2016). 
61. Ramsay, J.G.; Roizen, M. SmartTots: A public-private partnership between the United States Food and Drug Administration (FDA) and the International Anesthesia Research Society (IARS). Paediatr. Anaesth. 2012, 22, 969-972. [CrossRef] [PubMed]

62. Weiss, M.; Vutskits, L.; Hansen, T.G.; Engelhardt, T. Safe Anesthesia for Every Tot-The SAFETOTS initiative. Curr. Opin. Anaesthesiol. 2015, 28, 302-307. [CrossRef] [PubMed]

63. DiMaggio, C.; Sun, L.S.; Kakavouli, A.; Byrne, M.W.; Li, G. A retrospective cohort study of the association of anesthesia and hernia repair surgery with behavioral and developmental disorders in young children. J. Neurosurg. Anesth. 2009, 21, 286-291. [CrossRef] [PubMed]

64. Sprung, J.; Flick, R.P.; Wilder, R.T.; Katusic, S.K.; Pike, T.L.; Dingli, M.; Gleich, S.J.; Schroeder, D.R.; Barbaresi, W.J.; Hanson, A.C.; et al. Anesthesia for cesarean delivery and learning disabilities in a population-based birth cohort. Anesthesiology 2009, 111, 302-310. [CrossRef] [PubMed]

65. Wilder, R.T.; Flick, R.P.; Sprung, J.; Katusic, S.K.; Barbaresi, W.J.; Mickelson, C.; Gleich, S.J.; Schroeder, D.R.; Weaver, A.L.; Warner, D.O. Early exposure to anesthesia and learning disabilities in a Population-Based Birth Cohort. Anesthesiology 2009, 110, 796-804. [CrossRef] [PubMed]

66. Hattori, R.; Desimaru, M.; Nagayama, I.; Inoue, K. Autistic and developmental disorders after general anaesthetic delivery. Lancet 1991, 337, 1357-1358. [CrossRef]

67. Sylvester, G.C.; Khoury, M.J.; Lu, X.; Erickson, J.D. First-trimester anesthesia exposure and the risk of central nervous system defects: A population-based case-control study. Am. J. Public Health 1994, 84, 1757-1760. [CrossRef] [PubMed]

68. Bartels, M.; Althoff, R.R.; Boomsma, D.I. Anesthesia and cognitive performance in children: No evidence for a causal relationship. Twin Res. Hum. Genet. 2009, 12, 246-253. [CrossRef] [PubMed]

69. McCann, M.E.; Bellinger, D.C.; Davidson, A.J.; Soriano, S.G. Clinical research approaches to studying pediatric anesthetic neurotoxicity. Neurotoxicology 2009, 30, 766-771. [CrossRef] [PubMed]

70. Hays, S.R.; Deshpande, J.K. Newly postulated neurodevelopmental risks of pediatric anesthesia: Theories that could rock our world. J. Urol. 2013, 189, 1222-1228. [CrossRef] [PubMed]

71. Hays, S.R.; Deshpande, J.K. Newly postulated neurodevelopmental risks of pediatric anesthesia. Curr. Neurol. Neurosci. Rep. 2011, 11, 205-210. [CrossRef] [PubMed]

72. McCann, M.E.; Soriano, S.G. Is anesthesia bad for the newborn brain? Anesthesiol. Clin. 2009, 27, $269-284$. [CrossRef] [PubMed]

73. DiMaggio, C.; Sun, L.S.; Li, G. Early childhood exposure to anesthesia and risk of developmental and behavioral disorders in a sibling birth cohort. Anesth. Analg. 2011, 113, 1143-1151. [CrossRef] [PubMed]

74. Flick, R.P.; Katusic, S.K.; Colligan, R.C.; Wilder, R.T.; Voigt, R.G.; Olson, M.D.; Sprung, J.; Weaver, A.L.; Schroeder, D.R.; Warner, D.O. Cognitive and behavioral outcomes after early exposure to anesthesia and surgery. Pediatrics 2011, 128, e1053-e1061. [CrossRef] [PubMed]

75. Sprung, J.; Flick, R.P.; Katusic, S.K.; Colligan, R.C.; Barbaresi, W.J.; Bojanić, K.; Welch, T.L.; Olson, M.D.; Hanson, A.C.; Schroeder, D.R.; et al. Attention-Deficit/Hyperactivity Disorder After Early Exposure to Procedures Requiring General Anesthesia. Mayo Clin. Proc. 2012, 87, 120-129. [CrossRef] [PubMed]

76. Sun, L.S.; Li, G.; Miller, T.L.; Salorio, C.; Byrne, M.W.; Bellinger, D.C.; Ing, C.; Park, R.; Radcliffe, J.; Hays, S.R.; et al. Association between a single general anesthesia exposure before age 36 months and neurocognitive outcomes in later childhood. JAMA 2016, 315, 2312-2320. [CrossRef] [PubMed]

77. Rozé, J.C.; Denizot, S.; Carbajal, R.; Ancel, P.Y.; Kaminski, M.; Arnaud, C.; Truffert, P.; Marret, S.; Matis, J.; Thiriez, G.; et al. Prolonged sedation and/or analgesia and 5-year neurodevelopment outcome in very preterm infants: Results from the EPIPAGE cohort. Arch. Pediatr. Adolesc. Med. 2008, 162, 728-733. [CrossRef] [PubMed]

78. Kalkman, C.J.; Peelen, L.; Moons, K.G.; Veenhuizen, M.; Bruens, M.; Sinnema, G.; de Jong, T.P. Behavior and development in children and age at the time of first anesthetic exposure. Anesthesiology 2009, 110, 805-812. [CrossRef] [PubMed]

79. Hansen, T.G.; Pedersen, J.K.; Henneberg, S.W.; Pedersen, D.A.; Murray, J.C.; Morton, N.S.; Christensen, K. Academic performance in adolescence after inguinal hernia repair in infancy: A nationwide cohort study. Anesthesiology 2011, 114, 1076-1085. [CrossRef] [PubMed] 
80. Guerra, G.G.; Robertson, C.M.; Alton, G.Y.; Joffe, A.R.; Cave, D.A.; Dinu, I.A.; Creighton, D.E.; Ross, D.B.; Rebeyka, I.M.; Western Canadian Complex Pediatric Therapies Follow-up Group. Neurodevelopmental outcome following exposure to sedative and analgesic drugs for complex cardiac surgery in infancy. Paediatr. Anaesth. 2011, 21, 932-941. [CrossRef] [PubMed]

81. Ing, C.H.; DiMaggio, C.J.; Malacova, E.; Whitehouse, A.J.; Hegarty, M.K.; Feng, T.; Brady, J.E.; von Ungern-Sternberg, B.S.; Davidson, A.J.; Wall, M.M.; et al. Comparative analysis of outcome measures used in examining neurodevelopmental effects of early childhood anesthesia exposure. Anesthesiology 2014, 120, 1319-1332. [CrossRef] [PubMed]

82. Ko, W.R.; Liaw, Y.P.; Huang, J.Y.; Zhao, D.H.; Chang, H.C.; Ko, P.C.; Jan, S.R.; Nfor, O.N.; Chiang, Y.C.; Lin, L.Y. Exposure to general anesthesia in early life and the risk of attention deficit/hyperactivity disorder development: A nationwide, retrospective matched-cohort study. Paediatr. Anaesth. 2014, 24, 741-748. [CrossRef] [PubMed]

83. Ko, W.R.; Huang, J.Y.; Chiang, Y.C.; Nfor, O.N.; Ko, P.C.; Jan, S.R.; Lung, C.C.; Chang, H.C.; Lin, L.Y.; Liaw, Y.P. Risk of autistic disorder after exposure to general anaesthesia and surgery: A nationwide, retrospective matched cohort study. Eur. J. Anaesthesiol. 2015, 32, 303-310. [CrossRef] [PubMed]

84. Creagh, O.; Torres, H.; Rivera, K.; Morales-Franqui, M.; Altieri-Acevedo, G.; Warner, D. Previous exposure to Anesthesia and Autism Spectrum Disorder (ASD): A puerto rican population-based sibling cohort study. Bol. Asoc. Med. P. R. 2015, 107, 29-37. [PubMed]

85. Gleich, S.J.; Flick, R.; Hu, D.; Zaccariello, M.J.; Colligan, R.C.; Katusic, S.K.; Schroeder, D.R.; Hanson, A.; Buenvenida, S.; Wilder, R.T.; et al. Neurodevelopment of children exposed to anesthesia: Design of the Mayo Anesthesia Safety in Kids (MASK) study. Contemp. Clin. Trials. 2015, 41, 45-54. [CrossRef] [PubMed]

86. Hu, D.; Flick, R.P.; Gleich, S.J.; Scanlon, M.M.; Zaccariello, M.J.; Colligan, R.C.; Katusic, S.K.; Schroeder, D.R.; Hanson, A.C.; Buenvenida, S.L.; et al. Construction and characterization of a population-based cohort to study the association of anesthesia exposure with neurodevelopmental outcomes. PLOS ONE 2016, 11, e0155288. [CrossRef] [PubMed]

87. DiMaggio, C.; Sun, L.S.; Ing, C.; Li, G. Pediatric anesthesia and neurodevelopmental impairments: A Bayesian meta-analysis. J. Neurosurg. Anesth. 2012, 24, 376-381. [CrossRef] [PubMed]

88. Ing, C.; DiMaggio, C.; Whitehouse, A.; Hegarty, M.K.; Brady, J.; von Ungern-Sternberg, B.S.; Davidson, A.; Wood, A.J.; Li, G.; Sun, L.S. Long-term differences in language and cognitive function after childhood exposure to anesthesia. Pediatrics 2012, 130, e476-e485. [CrossRef] [PubMed]

89. Ing, C.; Wall, M.M.; DiMaggio, C.J.; Whitehouse, A.J.; Hegarty, M.K.; Sun, M.; von Ungern-Sternberg, B.S.; Li, G.; Sun, L.S. Latent class analysis of neurodevelopmental deficit after exposure to anesthesia in early childhood. J. Neurosurg. Anesthesiol. 2016. [CrossRef] [PubMed]

90. Davidson, A.J.; Becke, K.; de Graaff, J.; Giribaldi, G.; Habre, W.; Hansen, T.; Hunt, R.W.; Ing, C.; Loepke, A.; McCann, M.E.; et al. Anesthesia and the developing brain: A way forward for clinical research. Paediatr. Anaesth. 2015, 25, 447-452. [CrossRef] [PubMed]

91. Flick, R.P.; Nemergut, M.E.; Christensen, K.; Hansen, T.G. Anesthetic related neurotoxicity in the young and outcome measures: The devil is in the details. Anesthesiology 2014, 120, 1303-1305. [CrossRef] [PubMed]

92. Beers, S.R.; Rofey, D.L.; McIntyre, K.A. Neurodevelopmental assessment after anesthesia in childhood: Review of the literature and recommendations. Anesth. Analg. 2014, 119, 661-669. [CrossRef] [PubMed]

93. Diaz, L.K.; Gaynor, J.W.; Koh, S.J.; Ittenbach, R.F.; Gerdes, M.; Bernbaum, J.C.; Zackai, E.H.; Clancy, R.R.; Rehman, M.A.; Pennington, J.W.; et al. Increasing cumulative exposure to volatile anesthetic agents is associated with poorer neurodevelopmental outcomes in children with hypoplastic left heart syndrome. J. Thorac. Cardiovasc. Surg. 2016. [CrossRef] [PubMed]

94. Andropoulos, D.B.; Ahmad, H.B.; Haq, T.; Brady, K.; Stayer, S.A.; Meador, M.R.; Hunter, J.V.; Rivera, C.; Voigt, R.G.; Turcich, M.; et al. The association between brain injury, perioperative anesthetic exposure, and 12-month neurodevelopmental outcomes after neonatal cardiac surgery: A retrospective cohort study. Paediatr. Anaesth. 2014, 24, 266-274. [CrossRef] [PubMed]

95. Weiss, M.; Hansen, T.G.; Engelhardt, T. Ensuring safe anaesthesia for neonates, infants and young children: What really matters. Arch. Dis. Child. 2016, 101, 650-652. [CrossRef] [PubMed]

96. Wang, X.; Xu, Z.; Miao, C.-H. Current clinical evidence on the effect of general anesthesia on neurodevelopment in children: An updated systematic review with meta-regression. PLoS ONE 2014, 9, e85760. [CrossRef] [PubMed] 
97. Zhang, H.; Du, L.; Du, Z.; Jiang, H.; Han, D.; Li, Q. Association between childhood exposure to single general anesthesia and neurodevelopment: A systematic review and meta-analysis of cohort study. J. Anesth. 2015, 29, 749-757. [CrossRef] [PubMed]

98. Mann, G.E.; Kahana, M. The uncomfortable reality ... We simply do not know if general anesthesia negatively impacts the neurocognitive development of our small children. Int. J. Pediatr. Otorhinolaryngol. 2015, 79, 1379-1381. [CrossRef] [PubMed]

99. Nemergut, M.E.; Aganga, D.; Flick, R.P. Anesthetic neurotoxicity: What to tell the parents? Paediatr. Anaesth. 2014, 24, 120-126. [CrossRef] [PubMed]

100. Lei, S.; Davis, N.; Lee, M.; Ing, C. Engaging stakeholders in research related to anesthesia and neurodevelopment in children. J. Neurosurg. Anesthesiol. 2014, 26, 387-390. [CrossRef] [PubMed]

101. Lei, S.Y.; Hache, M.; Loepke, A.W. Clinical research into anesthetic neurotoxicity: Does anesthesia cause neurological abnormalities in humans? J. Neurosurg. Anesthesiol. 2014, 26, 349-357. [CrossRef] [PubMed]

102. Mintz, C.D.; Wagner, M.; Loepke, A.W. Preclinical research into the effects of anesthetics on the developing brain: Promises and pitfalls. J. Neurosurg. Anesthesiol. 2012, 24, 362-367. [CrossRef] [PubMed]

103. Gleich, S.; Nemergut, M.; Flick, R. Anesthetic-related neurotoxicity in young children: An update. Curr. Opin. Anaesthesiol. 2013, 26, 340-347. [CrossRef] [PubMed]

(C) 2016 by the author; licensee MDPI, Basel, Switzerland. This article is an open access article distributed under the terms and conditions of the Creative Commons Attribution (CC-BY) license (http://creativecommons.org/licenses/by/4.0/). 